Marine Research in Indonesia No. 18, 1977 : $13-15$.

\title{
ENVIRONMENTAL THREATS TO EAST AUSTRALIAN MANGROVE FORESTS AND TIDAL MARSHES
}

\author{
by
}

\author{
J.D.S. DAVIE ${ }^{1)}$ and E.J. HEGERL ${ }^{2)}$
}

\section{THE RESOURCE}

The east Australian coastline extends for over $7100 \mathrm{~km}$ from Cape York $\left(10^{\circ} 45^{\prime} \mathrm{S}\right)$ to Cape Howe $\left(37^{\circ} 31^{\prime} \mathrm{S}\right)$, the southern extent of the state of New South Wales (N.S.W.). Along this coastline mangrove forests and tidal marshes form an extensive resource which we will collectively refer to as "tidal wetlands"; It is estimated that 42\% of Queensland's $5200 \mathrm{~km}$ coastline is fringed with mangroves (pers. comm., DR. I. DAVIS, Geography Department, University of Queensland), but the total area of tidal wetlands has not yet been determined. The Queensland Fisheries Service is currently engage in a major project of mapping this resource (OLSEN personal communication). In N.S.W. tidal wetlands are much less extensive. GOODRICH (1970) estimated that they originally occupied 29,016 ha., but up to date figures are not available on how much of this resource has been destroyed.

Detailed documentation of the basic biological attributes of these environments followed the work of $\operatorname{MACNAE}(1966,1968)$ and has been underway for less than a decade. Since 1968, the Australian Littoral Society has been able to survey the fauna and flora of 18 sites along the coastline (see: HEGERL \& DAVIE personal communication, Fig. 1). The most extensive work has occurred in Careel Bay in central N.S.W., in Moreton Bay and Hervey Bay in southern Queensland, and in Cairns in northern Queensland. The objectives and the methodology employed in most of these surveys have been discussed by HEGERL \& DAVIE (personal communication) and many of the results have been documented (DAY 1975; ELLWAY \& HEGERL 1972; GRAHAM et al. 1975; HABITAT 1974; HEGERL 1975; HEGERL \& TimMins 1973; HegERL \& TARTE 1974; EutCHINGS \& RECHER 1974; LEWIS \& ELLWAY 1971; SHANCO 1975; SHANCO \& TIMMINS 1975; SHINE et al. 1973; WEATE 1975). In addition to these studies, a detailed investigation of some mangrove forests at Port Curtis in central Queensland have been initiated by the Southern Electric Authority of Queensland (SAENGER \& ROBSON personal communication).

1) School of Australian Environmental Studies, Griffith University, Nathan, 0 4111, Australia.

2) Australian Littoral Society, P.O. Box 82, St. Lucia, Q 4067, Australia. 


\section{J.D.S. DAVIE \& E.J. HEGERL}

\section{THE THREATS}

Despite the fact that less than 5 million Australians live on, or near, the east Australian coastline, the magnitude of industrial and agricultural activity, and the lifestyle and affluence of Australians have already had a substantial impact on the east coast mangrove forests and tidal marshes. Until recently, these areas have been regarded by most Australians as "worthless swamplands" which should be filled and used for other purposes. As a result, reclaimed tidal wetlands have been utilized as sites for urban and industrial developments, wharf facilities, airports, rubbish dumps, and agricultural activities.

Canal-estate housing developments have proved particularly destructive to tidal wetlands. In southern Queensland some $500 \mathrm{~km}$ of canals have been built, are under construction, or are being planned. Water pollution and flooding problems have arisen in these canals and concern is now being widely expressed about damage to recreational and commercial fisheries and bird-life. In addition the beaches of many canals have proved an extremely favourable habitat for biting midges (Ceratopoginidae). Recent proposals for additional canals have been strongly opposed by the public.

In most cases of tidal wetlands destruction that we have studied in eastern Australia, either alternative sites have been available for the development, or the proposal has proved of dubious economic benefit to the community.

\section{CONCLUSIONS}

Destruction of tidal wetlands in eastern Australia continues largely because the link between tidal wetlands and the life they support is not yet widely appreciated. Additional studies such as those of MARTOSUBROTO \& NAAMIN personal communication) are needed to show that tidal wetlands in an undisturbed state may produce the greatest benefits to the Australian people.

\section{REFERENCES}

DAY, R.W. 1975. A biological survey of Tuncurry Creek, N.S.W. Operculum 4(3 \& 4): 96 - 104. ELL WAY, C.P. and E.J. HEGERL 1972. The fishes of the Tweed River estuary (N.S.W.). Operculum 2(1): 16-23.

GOODRICH, G.N. 1970. A survey of wetlands of coastal New South Wales. C.S.I.R.O. Div. Wildlife Res. Tech. Memorandum, 5 : 36pp.

Graham, M., J. Grimshaw, E. Hegerl, J. McNalty \& R. Timmins 1975. Cairns Wetlands : a preliminary report. Operculum 4(3 \& 4): $117-148$. 


\section{ENVIRONMENTAL THREATS TO MANGROVE FORESTS}

Habitat 1974. An ecological study of Corio Bay, central Queensland. Printed consulting report. Habitat : Brisbane. 44 pp +4 pp. maps. HEGERL, E.J. 1975. The effects of flooding on Brisbane River mangroves. Operculum 4(3 \& 4): 156 - 157.

HEGERL, E.J. and D.M. TARTE 1974. A reconnaissance of the Capicorn Coast tidal wetlands. Operculum 4(2): 50 - 62.

HEGERL, E.J. and R. TIMMINS 1973. The Noosa River tidal swamps : a preliminary report on the flora and fauna. Operculum 3(4) : 38 - 43.

Hutchings, P,A. and H.R. RECHER 1974. The fauna of Careel Bay with comments on the ecology of mangrove and sea grass communities. Aust. Zool. 18(2) : 99 - 128.

LEWIS, A.D. and C.P. EllWAY 1971. Fishes of Tallebudgera Creek (Qld.). Operculum 1(3): 60 63.

Macnae, W. 1966. Mangroves in eastern and southern Australia. Aust. J. Bot. 14: 67 - 104. 1968. A general account of the fauna and flora of mangrove swamps and forests in the IndoWest-Pacific region. Adv. Mar. Biol. 6: 73 - 270.

SHANCO, P. 1975. Magnetic Island, north Queensland : a preliminary checklist of tidal wetlands molluscs. Operculum 4(3 \& 4) : 158 - 159.

Shanco, P. and R. TIMMINS 1975. Reconnaissance of southern Bustard Bay tidal wetlands. Operculum 4(3 \& 4): 149 - 154.

Shine, R., C.P. Ellway and E.J. Hegerl 1973. A biological survey of the Tallebudgera Creek estuary. Operculum 3(5\& 6) : $59-83$.

WeAtE, P. 1975. A study of the wetlands of the Myall River (N.S.W.). Operculum 4(3 \& 4) : 105 $-113$. 